\title{
Economics
}

\section{Variation in Executive Compensation and Allocation of Cash Flow}

\author{
Chihchung Chien ${ }^{1, *}$, Shikuan Chen ${ }^{2}$, Mingjen Chang ${ }^{3}$ \\ ${ }^{1}$ Department of Finance, Asia University, Taichung, Taiwan \\ ${ }^{2}$ Department of International Business, National Taiwan University, Taipei, Taiwan \\ ${ }^{3}$ Department of Economics, National Dong Hwa University, Hualien, Taiwan
}

\section{Email address:}

andrewchien@asia.edu.tw (Chihchung Chien),skchen@ntu.edu.tw (Shikuan Chen),mjchang@gms.ndhu.edu.tw (Mingjen Chang)

${ }^{*}$ Corresponding author

\section{To cite this article:}

Chihchung Chien, Shikuan Chen, Mingjen Chang. Variation in Executive Compensation and Allocation of Cash Flow. Economics. Vol. 9, No. 3, 2020, pp. 49-59. doi: 10.11648/j.eco.20200903.11

Received: May 31, 2020; Accepted: June 17, 2020; Published: July 4, 2020

\begin{abstract}
This study investigates whether the variation in executive compensation play an important role in allocation of internal generated cash flow. Several financial literature focus on the issue of cash-flow sensitivity on various uses of internally generated cash flow. Firms are able to distribute their incremental cash flow to payout dividends, reimburse debt, raise equity, hold cash as precautionary savings or increase the investment to obtain the growth opportunity in the future. However, a few studies investigate the change in cash-flow sensitivity on various uses after incorporating the variation in executive compensations and other control variables. According to academic theory of incentive-pay and agency problems, CEOs have incentive to allocate more cash flow to risky investment projects in order to increase their contingent rewards if there is more free cash flow in a firm. Accordingly, we propose that cash-flow sensitivity on investment and cash holding are more volatile than other uses in firms when we take account of variation in different types of executive compensation. This proposition highlight an interesting phenomenon that overinvestment directly connects to overpayment of CEOs. Moreover, we clarify that restriction on executive compensation, perhaps reduces the agency cost but it also forces firms to reduce managerial talent or effort such that cash-flow sensitivity of various uses would rely on the type of executive compensation. Using the cash-flow sensitivity model, we find that the variation in executive compensation would change the allocation of cash flow and lead to agency problems. After controlling the firm's characteristics, CEO's characteristics and governance characteristics, we highlight that time varying excess executive compensation significantly explain the cash-flow sensitivity on various uses. In particular, the performance-sensitive pay (incentive-pay) induced by self-serving motivation and unobserved CEO talent is responsible for variation in cash-flow sensitivity on internal cash flow allocation.
\end{abstract}

Keywords: Cash-flow Sensitivity, Excess Executive Compensation, Performance-sensitive Pay, Self-serving Motivation, Unobserved CEO Talent

\section{Introduction}

The allocation of internal cash flow is most important decision in business operation. Several financial literature focus on the issue of cash-flow sensitivity on various uses of internally generated cash flow. Firms are able to distribute their incremental cash flow to payout dividends, reimburse debt, raise equity, hold cash as precautionary savings or increase the investment to obtain the growth opportunity in the future. However, a few studies investigate the change in cash-flow sensitivity on various uses after incorporating the variation in executive compensation and other control variables.

According to academic theory of incentive-pay and agency problems, CEOs have incentive to allocate more cash flow to risky investment projects in order to increase their contingent rewards if there is more free cash flow in a firm. Accordingly, we propose that cash-flow sensitivity on investment and cash holding are more volatile than other uses in firms when we take account of variation in different types of executive compensation. This proposition highlight an interesting 
phenomenon that overinvestment directly connects to overpayment of CEOs.

Moreover, we clarify that restriction on executive compensation, perhaps reduces the agency cost but it also forces firms to reduce managerial talent or effort such that cash-flow sensitivity of various uses would rely on the type of executive compensations. Our evidence suggests that on average, different types of executive compensation in firms are consistent with efficiency arguments of cash-flow allocations. In addition, the interaction between executive characteristics and corporate governance presents important consequences for firm's allocation of internal cash flow and performance.

We develop our academic hypothesis regarding executive compensation effects and cash-flow allocation in Section 1. We describe our empirical data and measure of cash-flow sensitivity in Section 2. We test our hypothesis and investigate the effect on different types of executive compensations on cash-flow allocation in Section 3. Section 4 concludes.

\section{Data and Methodology}

This section describes our data and methodology. Our methodology first keep an eye on the analyses of Albuquerque, et al. [3] to decompose the peer pay effects on executive compensations into different components of managerial talent and self-serving behavior. Then we examine the effect of firm's characteristics and CEO pay in explaining the allocation of internal cash flow. Our purpose is to investigate the difference in executive compensations resulting from the talent and self-serving components those not only cause the high CEO payment but also change the cash-flow sensitivity on various uses.

We use the ExecuComp database to obtain the detailed information regarding executive compensation on top manager for listed companies in S\&P 1500. Our sample also includes those companies removed from the index but still trading during the period 1992-2014. We begin with 1992 because ExecuComp has the limited coverage of stock options grants (stgrttab) and long term incentive plan awards (ltawdtab) prior to that year. Moreover, data on executive compensation roughly can be divided into two categories: Individual characteristics such as title, age, gender, date became/left as CEO; Compensation: salary, bonus, restricted stock awards, option awards, non - equity incentive plan, deferred compensation, pension plan and shares owned. To ensure that any potential survivorship bias is not the problem to our dataset, our analysis covers both active and dead stocks (i.e. firms that were delisted at some point during the sample period).

The data we gather on characteristics of executives or top managers contain information whether the named executive is a member of the board and with the title of each executive. If the named executive is the CEO, we also obtain the year in which he became CEO and his ownership in the firm. We define the dummy "insider CEO" in a given year to be equal to one if no executive mentioned in the firm's executive compensation table other than the CEO sits on the board during that year. We define the dummy "duality CEO" to capture the CEO's powerful concentration. It would be equal to one if the CEO is both the chairman and the president or if he is the chairman and the firm has no president mentioned in the compensation table for that year.

As consequences of Albuquerque, et al. [3] show that the self-serving motivation and unobserved CEO talent are two important reasons for executives to require firm to pay high compensations. However, using the initial categories of the executive compensations is too complicated to isolate these two determinations. For simplicity, we construct three measures of executive compensation for our second investigation and obtain the orthogonal decomposition of them: (1) cash-based pay (i.e. salary, bonus and pension payments), (2) incentive-based pay (i.e. options, long-term incentive plans and other non-cash compensation) and (3) total pay (i.e. the sum of cash- and incentive-based pay).

We also control for the industry and size-adjusted compensation according to Bizjak, Lemmon and Thanh [11]. Firstly, we use the first two digital number of Standard Industrial Classification (SIC) to divide firms into the same industry. Secondly, firms in each industry are allocated into small-size or large-size groups based on their natural logarithm of total assets relative to the industry median in each year of classification. This controlling method for industry- and size-adjusted compensation is consistent with Albuquerque, et al. [3] to find out the matching firms (peer groups) with similarity in target firms' economic shocks. In addition, CEO compensation data are also matched at a firm-year level with CEO duality of responsibility (i.e., whether or not the CEO is also the chairman of the board), number of peers, and talent flows (i.e., firms from which one of the top five executives moved during 1992-2014).

\subsection{Decomposition of the Excess Compensation: Self-serving Versus Talent}

In this section, we discusses the influences of different executive compensation on allocation of internal cash flow. We argue that if executive compensation is driven by the self-serving behavior then allocation of internal cash flow is substantial related to the performance of corporate governance. In contrast, if executive compensation is paid for CEO talent then allocation of internal cash flow directly connect to capitalization of human capital.

The capitalization of human capital can be viewed as the trend or the long-run pattern of compensation such that executives slowly develop habits for higher or lower pay. Any excellent executive who has had a large compensation before can have an impact on how much he should require for new payment toady. This though can at least explain the "self-comparison" compensation. Another form of habit is "catch up with the Joneses" This external habit reflects that many executives seem more concerned about their compensation can stay ahead of their colleagues or competitors. 
To illustrate how the different drivers of executive compensations affect the allocation of internal cash flow, we estimate both self-comparison and catch up with the Joneses models and investigate variations of executive compensation.

We consider the spiritual model of habit formation following Abel [1] and Campbell and Cochrane [15] to determine the habit level of executive compensation by using various specifications of the following setting:

$$
X_{i t}=\phi X_{i t-1}+\lambda P R_{i t},
$$

where $X_{i t}$ denotes the natural logarithm of the long-term compensation level (habit) for firm $i$. Habits of compensations should move slowly in response to the self-comparison in the past and the reference of contemporaneous peer's compensation $\left(P R_{i t}\right)$. Equivalently, habits can also be shown in the iteration function of the peer's compensation or a series of compensations for catching up with the Joneses:

$$
X_{i t} \approx \lambda \sum_{k} \phi^{k} P R_{i, t-k} .
$$

In addition, we modify the model of Albuquerque, et al. [3] to estimate the reference of peer's compensation,

$$
P R_{i j t}=c_{0}+\sum \alpha_{k} \text { Firm }_{k, i j t}+\phi P e e r P a y_{i j t}+\varepsilon_{i j t},
$$

where $P R_{i j t}$ is the reference of contemporaneous peer's compensation if firm $i$ uses peer $j$ in determining executive compensation in year $t . \operatorname{Firm}_{k, j i t}$ is a set of characteristic variables that captures similarities between firms and their possible peers, and PeerPay $i j t$ is a measure of CEO compensation for the peer firm. After we obtain the habits of compensations, the excess CEO compensations is denoted by the difference between the realized compensations and the habits,

$$
E E C_{i t}=E C_{i t}-X_{i t}
$$

In many fields of corporate finance, peer influence would be difficult to identify due to the common shocks or unobserved heterogeneity. Accordingly, several different ways to identify the compensation peer groups, including Fama and French industries, 2- or 3-digit standard industry classification (SIC) codes, 6-digit global industry classification standard (GICS) codes and analyst-based peer groups [11]; [12]; [26]. For comparison of peer matching effects, we employ both of industry-based and analyst-based peer groups.

In our first setting, we use the 3-digit SIC code in identifying a peer group following Bizjak, et al. [12]. For each year, and within each industry (3-digit SIC), we rank all firms within each industry category based on the level of the prior period compensation measure and size of sales. This formation of peer groups based on industry would reflect the manner in which firms chooses peer groups for purposes of compensation comparison. In contrast, Kaustia and Rantala
[26] shows that the analyst-based method outperforms conventional industry classifications in producing homogenous groups because analysts' coverage choices directly reflect information regarding firm relatedness. Accordingly, we employ the peer identification which is based on actual links of common analysts between firms to find out the analyst-based peer groups.

The next step involves classifying excess CEO compensations into subcomponents of self-serving and talent according to proxies for self-serving and CEO talent. We expect the talent driving executive compensation to be positively related to the difficulty of the executives' tasks, which we assume are related to firm complexity and risk. Therefore, proxies for firm complexity such as size and volatility of stock returns should play an important role in determining the level of compensation. In addition, self-serving compensation may also be associated with other characteristics of the governance structure such as whether the CEO also serves as the chairman of the board or the degree of required board monitoring.

To test our idea, we decompose the executive compensations into subcomponents of self-serving and talent. In order to test whether the different executive compensation results from self-serving and CEO talent is potential explanation for allocation of internal cash flow, we the following regression:

$$
E E C_{i t}=\beta_{o}+\sum \beta_{m} \text { Talent }_{m, i t}+\sum \beta_{n} \text { Self_serving }_{n, i t}+\varepsilon_{i t},
$$

where the dependent variables are the excess compensation of board members and the CEO for self-comparison and catch up with the Joneses. The independent variables in these regressions include a set of proxies for CEO talent ( Talent $_{m, i t}$ ) and a set of governance characteristics as proxies for self-serving behavior that have been used in Albuquerque, et al. [3]. Our CEO talent measures include past abnormal performance of firms, the size of the firms the CEO has managed in the past, and CEO turnover.

To capture the performance of talent, we first define the CEO's abnormal returns on assets ( $\left.R \mathrm{OA}_{i, t-1}^{a b n}\right)$ by the average of the firm's return on assets relative to the industry return on assets over the years $t-3$ to $t-1$. Similarly, CEO's abnormal stock returns ( $\left.R E T_{i, t-1}^{a b n}\right)$ is the average of the firm's stock return measured relative to the S\&P 500 index over years $t-3$ to $t-1$. Moreover, we argue that the largest size of firm with complexity and risk is likely to be managed by the most talented CEOs, therefore we employ the natural logarithm of the average market capitalization of firms ( Size $_{i, t-1}^{c a p}$ ) for which the CEO worked over years $t-3$ to $t-1$. It is not necessary for CEOs to have worked at the same firm nor have served as CEO when we calculate these three measures over the previous 3-year period. Finally, CEO turnover ratio ( Turnover $_{i, t-1}^{C E O}$ ) is likely to increase when CEOs require the high level of compensations but their performance becomes worse. Given the poor performance of CEOs, CEOs would not be able to keep their positions if they do not allow to cut their compensation or otherwise they are enforced to leave. 
This means that the sensitivity of CEO turnover to performance is higher for relatively more talented CEOs.

As for self-serving motivation, we intended to use several proxies to capture the corporate governance structures. As our discussion above, the board of compensation committee is responsible for setting executive pay, executives can affect the result of choice when they also attend the committee. Hence, our proxies are expected to represent situations that the CEO could have more strongly influence on the pay-setting decision relative to the board's ability to control it. We follow the literature in our choice of corporate governance structures or self-serving motivation.

\subsection{Allocation of Internally Generated Cash Flow and Cash-flow Sensitivity}

In order to implement our empirical tests on the hypothesis of executive compensation effects on the internal cash-flow allocation, we need to measure how much various uses of flows is sensitive to the additional one dollar of internally generated cash-flow. We suppose that the more sensitivity of CEO's compensation to his performance would induce the more variation in the cash-flow sensitivity after controlling the firm's characteristics and CEO's characteristics such as the power concentrated in the hands of the CEO. "Cash-flow sensitivity" is a concept that solves system equations to determine the allocation of firm's internally generated cash flow to various uses by using the seemly unrelated regression. For simplicity, focusing on the estimation of individual use of cash flow, Chang, et al. [19] impose some constraints on coefficients of regresions for various uses such that fund of cash outflow exactly equals to fund of cash inflow,

$$
\Delta \operatorname{Cash}_{t}+\operatorname{Inv} v_{t}+\operatorname{Div}_{t}-\Delta D_{t}-\Delta E_{t}=C F_{t},
$$

where the uses of funds include the change in cash holdings $\left(\Delta \operatorname{Cash}_{t}\right)$, investment $\left(I n v_{t}\right)$, and cash dividends ( $\left.D i v_{t}\right)$. The sources of funds comprise the internally generated cash flow $\left(C F_{t}\right)$ and external financing that consists of the net debt issuance $\left(\Delta D_{t}\right)$ and the net equity issuance $\left(\Delta E_{t}\right) .-\Delta D_{t}$ and $-\Delta E_{t}$ represent net reductions in external financing, which are regarded as uses of funds.

Our extended models regress various uses of cash on internal cash flow $\left(C F_{t}\right)$, the market-to-book ratio $\left(M B_{t-1}\right)$ as a proxy for investment opportunities, the excess CEO compensations $\left(E E C_{t-1}\right)$, and other control variables $\left(Y_{k, t-1}\right)$ for firm $i$ at the end of year $t$. We also include firm dummies $\left(f_{i}\right)$ to control the unobserved heterogeneity and calendar dummies $\left(q_{t}\right)$ to control the time effects. All variables in cash-flow identify in Equation (6) are divided by the book value of assets, as an additional control for firm size. Accordingly, the seeming unrelated regression (SUR) are written as follows:

$$
\begin{aligned}
\Delta \text { Cash }_{i, t} & =\alpha^{\Delta C a s h} C F_{i, t}+\beta^{\Delta C a s h} M B_{i, t-1}+\gamma^{\Delta C a s h} E E C_{i, t-1}+\sum_{k} \lambda_{k}^{\Delta \text { Cash }} Y_{i, k, t-1}+f_{i}+q_{t}+\varepsilon_{i, t}^{\Delta \text { Cash }}, \\
I n v_{i, t} & =\alpha^{i n v} C F_{i, t}+\beta^{i n v} M B_{i, t-1}+\gamma^{i n v} E E C_{i, t-1}+\sum_{k} \lambda_{k}^{i n v} Y_{i, k, t-1}+f_{i}+q_{t}+\varepsilon_{i, t}^{i n v} \\
\operatorname{Div}_{i, t} & =\alpha^{D i v} C F_{i, t}+\beta^{D i v} M B_{i, t-1}+\gamma^{D i v} E E C_{i, t-1}+\sum_{k} \lambda_{k}^{D i v} Y_{i, k, t-1}+f_{i}+q_{t}+\varepsilon_{i, t}^{D i v} \\
\Delta D_{i, t} & =\alpha^{\Delta D} C F_{i, t}+\beta^{\Delta D} M B_{i, t-1}+\gamma^{\Delta D} E E C_{i, t-1}+\sum_{k} \lambda_{k}^{\Delta D} Y_{i, k, t-1}+f_{i}+q_{t}+\varepsilon_{i, t}^{\Delta D} \\
\Delta E_{i, t} & =\alpha^{\Delta E} C F_{i, t}+\beta^{\Delta E} M B_{i, t-1}+\gamma^{\Delta E} E E C_{i, t-1}+\sum_{k} \lambda_{k}^{\Delta E} Y_{i, k, t-1}+f_{i}+q_{t}+\varepsilon_{i, t}^{\Delta E}
\end{aligned}
$$

The allocation of cash flow across various uses is captured by the coefficients of $C F_{t}$ in Equation (7). We impose serious excess CEO compensation constraints on cash-flow identify, cash holdings, investment, dividend, and financing decisions are made together and they are subject to cash-flow identity in Equation (6). Therefore, internally generated cash flow must equal uses of cash flow and the cash-flow sensitivities of various uses of cash flow must add to unity. The coefficient estimates in Equation (7) must satisfy the following conditions,

$$
\begin{gathered}
\alpha^{\Delta C a s h}+\alpha^{i n v}+\alpha^{D i v}-\alpha^{\Delta D}-\alpha^{\Delta E}=1, \\
\beta^{\Delta C a s h}+\beta^{i n v}+\beta^{D i v}-\beta^{\Delta D}-\beta^{\Delta E}=0, \\
\gamma^{\Delta C a s h}+\gamma^{i n v}+\gamma^{D i v}-\gamma^{\Delta D}-\gamma^{\Delta E}=0, \\
\lambda_{k}^{\Delta C a s h}+\lambda_{k}^{i n v}+\lambda_{k}^{D i v}-\lambda_{k}^{\Delta D}-\lambda_{k}^{\Delta E}=0 .
\end{gathered}
$$

The adding-up constraint (8) reflects the accounting identity that uses of cash equal sources of cash without taking account for excess CEO compensation constraints. In other words, a one-dollar increase in internal cash flow needs to be used to adjust the change in cash holdings, investment, cash dividends payout, or reduce outstanding debt or equity. Other constraints specify that the total response across different uses and sources of funds must sum to zero if the shock stems from an exogenous or predetermined variable that represents neither a use nor a source of funds in the current period.

As for the control variables ( $\left.Y_{k, t-1}\right)$, we take account of firm's characteristics, CEO's characteristics and governance characteristics. We use the net tangibility-to-asset ratio (Tangibility) as the measure of firm's tangible assets to control the industrial difference of capital intensity. We also include the leverage ratio ( $D / A$ ) defined as long-term debt divided by total assets. Moreover, CEO's characteristics are identified by CEO's gender ( $\left.C E O^{\text {Gender }}\right)$, CEO's tenure $\left(C E O^{\text {Tenure }}\right)$ and whether CEO is promoted outside the company or not 
$\left(C E O^{\text {Internal }}\right)$. Other governance characteristics are incorporated as additional controls for firm's prospects of governance performance. For example, board size ( Board ), non-executive directors ( Dirs ${ }^{\text {Non }}$ ) and ownership concentration ( $O w n^{\text {Concen }}$ ) are used to measure the power concentration for director of board. Similarly, executive ownership ( $\left.C E O^{\text {Owner }}\right)$ and CEO duality $\left(C E O^{\text {Dual }}\right)$ capture the decision-making power of CEO. We expect the higher the number of relevant decision-makers, the less powerful the CEO is likely to be. Thus, we mostly pay attention on the CEO power over the board and other top executives as a consequence of his formal position. More details of variables are shown in Table 1.

Table 1. Variable definitions and descriptions.

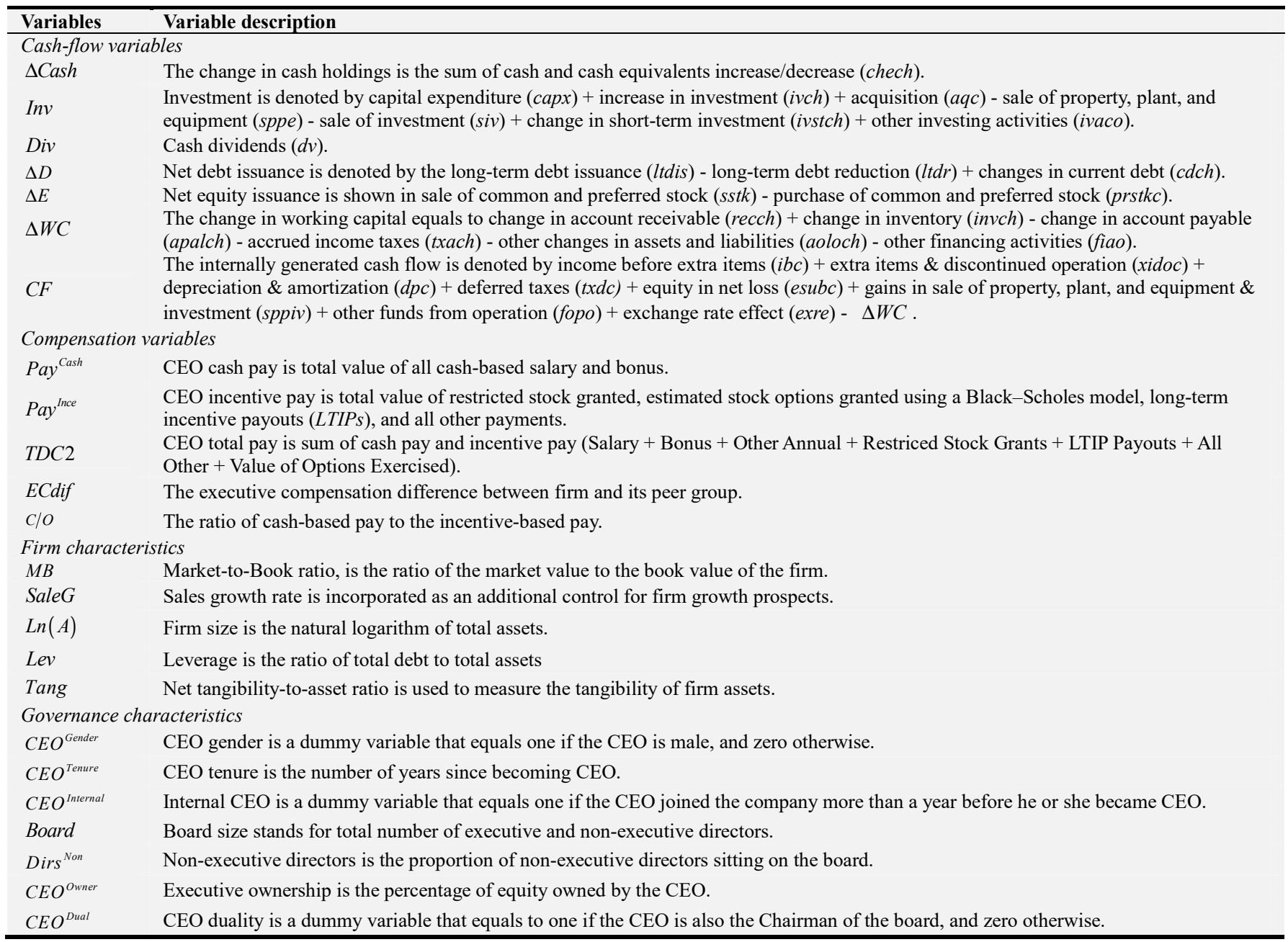

Notes: Variables are defined using flow-of-funds data of the Compustat. The variable definitions follow the statement of cash flows in reporting flow-of-funds data. The Compustat variable names are italicized and provided in parentheses. In addition, compensation data are provided by Execucomp

\section{Main Results}

\subsection{Self-comparison Executive Compensation and Allocation of Internal Cash Flow in Various Uses}

In our work, we try to examine whether CEO or members at the top of the managerial hierarchy are participating in allocation of internal cash flow if their executive compensations are sensitive to performance. In contrast, if a firm's internal cash flow allocation process typically consists of a horse race, then optimal executive compensation tends to be equal such that CEOs are not beneficial from rebalance of cash flow. However, if the CEO has power to conducts a competition for various uses of cash-flow to increase his interests, then it may be difficult to involve efficiency in allocation of internal cash flow. In this case, the firm will be more likely to cut executive compensations to increase the sensitivity of CEO performance. Therefore, we replace actual excess executive compensations with the prediction of excess executive compensations estimated by a set of proxies for CEO talent and self-serving.

In Table 2, we present summary statistics concerning select firm's cash-flow variables characteristics, executive compensation, governance characteristics, and measures of a CEO's power to influence internal cash flow allocations. As reported in Panel A, the accumulation of the means of various uses of cash flows is very close to unity, suggesting cash flow allocation are constrained by cash flow identify. In Panel B, 
we calculate the mean of salary and bonus in cash pay for catching up with the Joneses and mean of stock and options pay-for-performance incentives. The average CEO gains the similar compensation about $\$ 0.58$ million for both types. There is, however, substantial cross-sectional variation in pay-for-performance, as the standard deviation for this measure is larger than the standard deviation of salary and bonus in cash.

Since we want to examine how corporate governance explicitly affects the cash flow sensitivity to the difference of executive compensation, we control for governance characteristics or CEO entrenchment measures in the compensation regressions and examine their impact directly in subsequent tests. Thus, the pay variations due to poor internal control and managerial entrenchment are captured in our total compensation measure. In an average firm, over $94 \%$ of the CEO are male, just over $21 \%$ of CEO has dual positions, $95 \%$ of non-executive directors sitting on the board and CEO hold about $31 \%$ of outstanding shares. The average board consists of 7.5 directors and the mean of CEO tenure is 6 years.

Table 2. Descriptive statistics of variables.

\begin{tabular}{|c|c|c|c|c|c|c|}
\hline & $\mathbf{N}$ & Mean & Me & S. D. & Min & $\operatorname{Max}$ \\
\hline \multicolumn{7}{|c|}{ Panel A. Allocation of internally generated cash flow } \\
\hline \multicolumn{7}{|c|}{ Cash-flow variables } \\
\hline$\Delta$ Cash & 67284 & 0.006 & 0.003 & 0.053 & -0.646 & 0.939 \\
\hline $\operatorname{Inv}$ & 67284 & 0.084 & 0.058 & 0.096 & -0.273 & 1.005 \\
\hline Div & 67284 & 0.017 & 0.011 & 0.026 & 0.000 & 0.540 \\
\hline$\Delta D$ & 67284 & 0.011 & -0.000 & 0.075 & -0.367 & 0.804 \\
\hline$\Delta E$ & 67284 & -0.020 & -0.003 & 0.060 & -0.535 & 0.922 \\
\hline$C F$ & 67284 & 0.115 & 0.114 & 0.071 & -0.760 & 0.703 \\
\hline DifCF & 67284 & 0.005 & 0.005 & 0.003 & 0.000 & 0.010 \\
\hline \multicolumn{7}{|c|}{ Panel B. Executive Compensation and characteristics of firm, CEO and governance } \\
\hline \multicolumn{7}{|c|}{ Compensation variables } \\
\hline Pay ${ }^{\text {Cash }}$ & 649129 & 586.26 & 433.547 & 670.30 & 0.000 & 102448.76 \\
\hline Pay Ince & 336398 & 572.692 & 145.372 & 2319.3 & 0.000 & 600347.35 \\
\hline$T D C 2$ & 649129 & 1821.0 & 983.57 & 3886.1 & 0.000 & 706119.85 \\
\hline ECdif & 630242 & -165.98 & -125.79 & 915.06 & -2553.64 & 2311.77 \\
\hline$C / O$ & 241168 & 2.277 & 1.093 & 19.202 & 0.000 & 3366.355 \\
\hline \multicolumn{7}{|c|}{ Firm characteristics } \\
\hline$M B$ & 626231 & 1.073 & 0.864 & 0.806 & 0.002 & 9.161 \\
\hline SaleG & 626231 & 0.046 & 0.049 & 0.160 & -1.517 & 1.010 \\
\hline $\operatorname{Ln}(A)$ & 626231 & 8.130 & 7.969 & 1.645 & 3.208 & 13.081 \\
\hline Lev & 626231 & 0.581 & 0.570 & 0.217 & 0.055 & 2.358 \\
\hline Tang & 626231 & 0.331 & 0.268 & 0.228 & 0.003 & 0.970 \\
\hline \multicolumn{7}{|c|}{ Governance characteristics } \\
\hline$C E O^{\text {Gender }}$ & 649129 & 0.944 & 1.000 & 0.229 & 0.000 & 1.000 \\
\hline$C E O^{\text {Tenure }}$ & 162792 & 6.121 & 4.917 & 8.338 & 0.000 & 41.417 \\
\hline Board & 324280 & 7.448 & 7.000 & 3.149 & 0.000 & 49.000 \\
\hline $\operatorname{Dirs}^{\text {Non }}$ & 324223 & 0.952 & 1.000 & 0.083 & 0.000 & 1.000 \\
\hline$C E O^{\text {Owner }}$ & 592533 & 0.311 & 0.231 & 0.280 & 0.000 & 1.000 \\
\hline$C E O^{\text {Dual }}$ & 649129 & 0.210 & 0.000 & 0.407 & 0.000 & 1.000 \\
\hline
\end{tabular}

Notes: This table reports the mean, median, standard deviation, minimum and maximum values of dependent variables regarding the allocation of internally generated cash flow (cash-flow variables). Independent variables include the executive compensation related variables, characteristics of firm and CEO as well as corporate governance.

Table 3 presents a multivariate analysis of cash-flow sensitivity to the allocation of internal cash flow and self-comparison executive compensation (using salary and bonus and equity compensation as an appropriate total compensation). We first implement the panel regression with fixed effect for various uses on internal cash flow, and executive compensation after controlling the firm characteristics. Next, we include the governance factors in regression to estimate the sensitivity to uses of internal cash flow for our overall sample. If the total executive compensation is an important determinant, firms of the most influence (i.e., firms with the highest level of abnormal CEO pay) should experience significant cash-flow sensitivity. This is precisely what we expect. When pay is measured by the sum of cash pay and incentive pay, we find that cash-flow sensitivity on the cash holding reacts positively for firms with the average paid CEOs (a significantly positive $0.2 \%$ ) while cash-flow sensitivity on investment reacts negatively for firms with the average paid CEOs (a negative $0.1 \%$ ). 
Table 3. Allocation of internal cash flow and self-comparison executive compensation.

\begin{tabular}{|c|c|c|c|c|c|}
\hline & (1) $\Delta$ Cash $_{t}$ & (2) $I n v_{t}$ & (3) $D i v_{t}$ & (4) $\Delta D_{t}$ & (5) $\Delta E_{t}$ \\
\hline \multicolumn{6}{|c|}{ Panel A Allocation of $C F$ and executive compensation } \\
\hline$C F_{t}$ & $0.079^{* * *}(9.23)$ & $0.568^{* * *}(40.34)$ & $0.114^{* * *}(32.09)$ & $-0.03^{* *}(-2.45)$ & $-0.204^{* * *}(-20.78)$ \\
\hline$T D C 2_{t-1}$ & $0.002^{* * *}(4.79)$ & $-0.01^{* *}(-2.12)$ & $0.001^{*}(1.71)$ & $-0.02^{* * *}(-3.64)$ & $0.003^{* * *}(6.34)$ \\
\hline$M B_{t-1}$ & $0.003^{* * *}(4.45)$ & $0.001(0.23)$ & $0.003^{* * *}(10.17)$ & $0.006^{* * *}(6.09)$ & $-0.001(-0.11)$ \\
\hline SaleG $_{t-1}$ & $-0.002(-0.44)$ & $0.075^{* * *}(14.06)$ & $-0.01^{* * *}(-6.68)$ & $0.029^{* * *}(4.33)$ & $0.044^{* * *}(11.88)$ \\
\hline $\operatorname{Ln}\left(A_{t-1}\right)$ & $0.001^{* *}(2.28)$ & $-0.02^{* * *}(-2.99)$ & $0.002^{* * *}(6.59)$ & $0.001(1.62)$ & $-0.001^{* *}(-2.02)$ \\
\hline$L e v_{t-1}$ & $-0.01^{* * *}(-3.54)$ & $0.021^{* * *}(4.50)$ & $-0.01^{* * *}(-3.69)$ & $0.009^{* *}(2.20)$ & $-0.003(-1.02)$ \\
\hline Tang $_{t-1}$ & $-0.03^{* * *}(-12.86)$ & $0.093^{* * *}(24.22)$ & $-0.08^{* * *}(-8.90)$ & $0.035^{* * *}(10.28)$ & $0.018^{* * *}(6.80)$ \\
\hline \multicolumn{6}{|c|}{ Panel B Allocation of CF, executive compensation and governance } \\
\hline$C F_{t}$ & $0.079^{* * *}(9.18)$ & $0.572^{* * *}(40.63)$ & $0.115^{* * *}(32.42)$ & $-0.03^{* *}(-2.08)$ & $-0.205^{* * *}(-20.86)$ \\
\hline$T D C 2_{t-1}$ & $0.002^{* * *}(4.79)$ & $-0.001^{* *}(-2.21)$ & $0.002(1.44)$ & $-0.01^{* * *}(-3.98)$ & $0.002^{* * *}(6.46)$ \\
\hline$M B_{t-1}$ & $0.001^{* * *}(4.92)$ & $0.001(0.15)$ & $0.003^{* * *}(9.82)$ & $0.006^{* * *}(5.93)$ & $0.001(0.31)$ \\
\hline Sale $G_{t-1}$ & $-0.005(-0.15)$ & $0.075^{* * *}(13.94)$ & $-0.01^{* * *}(-7.26)$ & $0.019^{* * *}(4.01)$ & $0.045^{* * *}(12.17)$ \\
\hline $\operatorname{Ln}\left(A_{t-1}\right)$ & $0.001^{* *}(2.10)$ & $-0.01^{* * *}(-3.87)$ & $0.001^{* * *}(5.47)$ & $0.004(0.67)$ & $-0.001^{* *}(-2.40)$ \\
\hline$L e v_{t-1}$ & $-0.01^{* * *}(-4.00)$ & $0.024^{* * *}(4.92)$ & $-0.04^{* * *}(-3.17)$ & $0.012^{* * *}(2.72)$ & $-0.005(-1.38)$ \\
\hline Tang $_{t-1}$ & $-0.03^{* * *}(-12.87)$ & $0.092^{* * *}(23.70)$ & $-0.01^{* * *}(-9.59)$ & $0.034^{* * *}(9.61)$ & $0.018^{* * *}(6.67)$ \\
\hline$C E O^{\text {Gender }}$ & $0.024^{* * *}(5.01)$ & $0.027^{* * *}(3.50)$ & $0.009^{* * *}(4.46)$ & $0.026^{* * *}(3.71)$ & $0.032^{* * *}(6.07)$ \\
\hline$C E O^{\text {Tenure }}$ & $-0.001(-1.38)$ & $0.005^{* * *}(4.69)$ & $-0.01^{* * *}(-2.88)$ & $0.004^{* * *}(4.78)$ & $-0.001^{*}(-1.70)$ \\
\hline Dirs ${ }^{\text {Non }}$ & $0.028^{* * *}(4.28)$ & $-0.002(-0.02)$ & $-0.01^{* * *}(-6.19)$ & $-0.02^{* * *}(-2.25)$ & $0.032^{* * *}(4.30)$ \\
\hline$C E O^{O_{\text {wner }}}$ & $0.005^{* *}(2.55)$ & $-0.01^{* *}(-2.30)$ & $-0.03^{* * *}(-4.10)$ & $-0.01^{* * *}(-2.71)$ & $0.004(1.54)$ \\
\hline Industry FE/year FE & Yes & Yes & Yes & Yes & Yes \\
\hline No. of firms & 711 & 711 & 711 & 711 & 711 \\
\hline
\end{tabular}

Notes: Coefficients significant at the $10 \%, 5 \%$, and $1 \%$ levels are indicated by $* * *$, and $* * *$, respectively. The t-statistics are presented in parentheses.

These results are consistent with the self-interest hypothesis The cash flow sensitivity on various uses of cash flow suggests that controlling for cash flow identity, firm characteristics, governance and the total executive compensation could help increase the cash holding to pay for top managers and reduce the allocation of internal cash flow to investment for firms, thus the benefits of their shareholders are undetermined. We caution the readers not to interpret the positive cash flow sensitivity on cash holding as the precautionary savings due to the negative relationship between executive compensation and short-term subsequent returns and negative coefficient on investment even though the excessive exposure of low-incentive-pay firms to idiosyncratic risk could earn positive abnormal returns [8]. The cash flow sensitivity on cash holding and investment to total compensation is consistent with the intuition that allowing CEOs (top managers) to determine their total executive compensation for firms through allocation of internal cash flow can do more than overpay.

We also analyze the impact of corporate governance. We observe that the relationship between cash flow sensitivity and CEO gender is positive and significant. This finding supports the argument that male CEO can have aggressive actions to the management, which can lead to higher cash-flow sensitivity. However, we note that the relation between the cash flow sensitivity on various uses and a firm's corporate governance quality need not be consistent or even significant. As a firm starts to deviate from good corporate governance, giving top managers an opportunity to voice their dissatisfaction with total executive compensation may deteriorate governance and performance, thus decreasing firm value. If a firm's corporate governance is so bad that the CEO is entrenched, the board may choose to ignore shareholder discontent. Ultimately, the relation between governance measures and cash flow sensitivity to executive compensation is an empirical issue. Our analysis recognizes the possibility of effects by looking at average of governance measures.

\subsection{Comparative Executive Compensation by Using Industry-based Peer Group and Allocation of Internal Cash Flow in Various Uses}

It is no surprising that characteristics of executive compensation within industry-based peer group would influence the cash flow sensitivity on various uses to each firm. In subsequent analysis, we examine the distinct executive compensation within industry-based peer group that may influence the impact of the cash flow sensitivity. Table 4 reveals the relation between the cash flow sensitivity to the difference of executive compensation for firms within industry-based peer group.

Panels A examine whether the difference of executive compensation between a firm and its industry-based peer group impacts on the allocation of internal cash flow, while Panels B incorporates the corporate governance to a firm's cash flow sensitivity. Looking at Column 1, the coefficient estimates for excess executive compensation is positive and significant, suggesting that CEOs receive higher compensation in firms than their peer firms would have higher cash-flow sensitivity of cash holding. Excess executive compensation does not rely on investment, as the coefficient in Column 2 shows. Furthermore, we investigate the impact of excess executive compensation on cash-flow sensitivity of 
dividend payout, debt issued and equity issued. The coefficient estimate for excess executive compensation is negative and significant for the dividend payout and the fraction of debt issued, while it is positive, but not significant for equity issued. Overall, we find significant evidence of a large allocation to cash holding by CEOs providing high compensation for themselves.

Table 4. Allocation of internal cash flow and adjustment of executive compensation by using industry-based peer group.

\begin{tabular}{|c|c|c|c|c|c|}
\hline & (1) $\Delta C_{a s h}$ & (2) $I n v_{t}$ & (3) $\mathrm{Div}_{t}$ & (4) $\Delta D_{t}$ & (5) $\Delta E_{t}$ \\
\hline \multicolumn{6}{|c|}{ Panel A Allocation of $C F$ and executive compensation } \\
\hline$C F_{t}$ & $0.086^{* * *}(10.01)$ & $0.565^{* * *}(40.41)$ & $0.113^{* * *}(32.98)$ & $-0.038^{* * *}(-2.98)$ & $-0.196^{* * *}(-20.05)$ \\
\hline$T D C 2_{t-1}$ & $0.002^{* * *}(4.39)$ & $0.007(1.17)$ & $-0.003^{* * *}(-19.10)$ & $-0.001^{*}(-1.69)$ & $0.006(1.33)$ \\
\hline$M B_{t-1}$ & $0.003^{* * *}(4.55)$ & $0.001(0.17)$ & $0.003^{* * *}(10.52)$ & $0.006^{* * *}(6.01)$ & $0.001(0.03)$ \\
\hline Sale $_{t-1}$ & $-0.001(-0.30)$ & $0.074^{* * *}(13.92)$ & $-0.008^{* * *}(-6.21)$ & $0.020^{* * *}(4.18)$ & $0.045^{* * *}(12.17)$ \\
\hline $\operatorname{Ln}\left(A_{t-1}\right)$ & $0.002(0.51)$ & $-0.001^{* *}(-2.19)$ & $0.008^{* * *}(5.19)$ & $0.002^{* * *}(3.47)$ & $-0.002^{* * *}(-5.26)$ \\
\hline $\operatorname{Lev}_{t-1}$ & $-0.010^{* * *}(-3.41)$ & $0.021^{* * *}(4.48)$ & $-0.005^{* * *}(-4.03)$ & $0.009^{* *}(2.13)$ & $-0.001(-0.92)$ \\
\hline Tang $_{t-1}$ & $-0.031^{* * *}(-13.39)$ & $0.094^{* * *}(24.63)$ & $-0.009^{* * *}(-9.79)$ & $0.037^{* * *}(10.71)$ & $0.016^{* * *}(6.13)$ \\
\hline \multicolumn{6}{|c|}{ Panel B Allocation of CF, executive compensation and governance } \\
\hline$C F_{t}$ & $0.085^{* * *}(9.99)$ & $0.568^{* * *}(40.70)$ & $0.114^{* * *}(33.29)$ & $-0.034^{* * *}(-2.67)$ & $-0.196^{* * *}(-20.10)$ \\
\hline$T D C 2_{t-1}$ & $0.002^{* * *}(4.30)$ & $0.001(1.10)$ & $-0.003^{* * *}(-19.13)$ & $-0.001^{*}(-1.92)$ & $0.006(1.34)$ \\
\hline$M B_{t-1}$ & $0.003^{* * *}(5.00)$ & $0.001(0.07)$ & $0.003^{* * *}(10.40)$ & $0.006^{* * *}(5.84)$ & $0.001(0.49)$ \\
\hline Sale $_{t-1}$ & $-0.001(-0.04)$ & $0.074^{* * *}(13.82)$ & $-0.009^{* * *}(-6.91)$ & $0.018^{* * *}(3.88)$ & $0.046^{* * *}(12.40)$ \\
\hline $\operatorname{Ln}\left(A_{t-1}\right)$ & $0.002(0.36)$ & $-0.002^{* * *}(-3.27)$ & $0.001^{* * *}(5.21)$ & $0.002^{* *}(2.32)$ & $-0.003^{* * *}(-5.20)$ \\
\hline $\operatorname{Lev}_{t-1}$ & $-0.011^{* * *}(-3.85)$ & $0.024^{* * *}(4.94)$ & $-0.005^{* * *}(-3.84)$ & $0.012^{* * *}(2.64)$ & $-0.004(-1.31)$ \\
\hline Tang $_{t-1}$ & $-0.032^{* *}(-13.44)$ & $0.093^{* * *}(24.18)$ & $-0.010^{* * *}(-10.63)$ & $0.035^{* * *}(10.12)$ & $0.016^{* * *}(5.93)$ \\
\hline$C E O^{\text {Gender }}$ & $0.021^{* * *}(5.15)$ & $0.026^{* * *}(3.43)$ & $0.009^{* * *}(4.67)$ & $0.025^{* * *}(3.59)$ & $0.034^{* * *}(6.26)$ \\
\hline$C E O^{\text {Tenure }}$ & $-0.001(-1.52)$ & $0.005^{* * *}(4.57)$ & $-0.001^{*}(-1.79)$ & $0.004^{* * *}(4.80)$ & $-0.001(-1.64)$ \\
\hline $\operatorname{Dirs}^{\text {Non }}$ & $0.026^{* * *}(3.98)$ & $0.001(0.13)$ & $-0.017^{* * *}(-6.48)$ & $-0.012^{* *}(-2.00)$ & $0.029^{* * *}(3.88)$ \\
\hline$C E O^{\text {Owner }}$ & $0.005^{* *}(2.36)$ & $-0.009^{* * *}(-2.58)$ & $-0.002^{*}(-1.72)$ & $-0.008^{* * *}(-2.76)$ & $0.004^{*}(1.84)$ \\
\hline Industry FE/year FE & Yes & Yes & Yes & Yes & Yes \\
\hline No. of firms & 711 & 711 & 711 & 711 & 711 \\
\hline
\end{tabular}

Notes: Coefficients significant at the $10 \%, 5 \%$, and $1 \%$ levels are indicated by $*, * *$, and $* * *$, respectively. The t-statistics are presented in parentheses.

The opposite seems, indeed, to be true: firms with higher excess compensation pay less dividends to their shareholders than their peer group firms. In fact, we have some evidence that allocation of cash flow to cash holding for firms with the positive excess compensation is relatively stronger than that for peer firms. This finding is consistent with the hypothesis that excess executive compensation can increase the sensitivity on cash holding while reduce the sensitivity on dividend payout to the firm. Thus, a firm with excess executive compensation would be more likely to allocate the internal cash flow to cash holding for purposes of self-interest or precautionary savings and would be more prone to pay lower dividends.

Table 5. Allocation of internal cash flow and distinct type of executive compensation by using industry-based peer group.

\begin{tabular}{|c|c|c|c|c|c|}
\hline & (1) $\Delta$ Cash $_{t}$ & (2) Inv & (3) $\mathrm{Div}{ }_{t}$ & (4) $\Delta D_{t}$ & (5) $\Delta E_{t}$ \\
\hline \multicolumn{6}{|c|}{ Panel A Allocation of CF, importance and frequency of executive compensation } \\
\hline$C F_{t}$ & $0.080^{* * *}(9.07)$ & $0.613^{* * *}(40.44)$ & $0.124^{* * *}(34.41)$ & $-0.011(-0.83)$ & $-0.169^{* * *}(-16.76)$ \\
\hline$E C d i f_{t-1}$ & $-0.002(-0.55)$ & $0.004(0.68)$ & $-0.003^{* * *}(-20.80)$ & $-0.001^{* *}(-2.11)$ & $-0.002^{* * *}(-3.59)$ \\
\hline$L P G_{t-1}$ & $-0.004(-0.19)$ & $0.007^{*}(1.79)$ & $-0.003^{* * *}(-3.78)$ & $-0.003(-0.80)$ & $0.005^{*}(1.84)$ \\
\hline$S P G_{t-1}$ & $0.008(0.57)$ & $-0.005^{*}(-1.94)$ & $-0.003^{* * *}(-4.09)$ & $-0.004^{* *}(-2.01)$ & $-0.002(-1.02)$ \\
\hline Payrise $_{t-1}$ & $0.007^{* * *}(4.18)$ & $-0.008^{* * *}(-3.02)$ & $-0.008(-1.24)$ & $-0.009^{* *}(-4.03)$ & $0.007^{* * *}(4.21)$ \\
\hline Paycut $_{t-1}$ & $0.001(1.11)$ & $0.007^{* * *}(2.80)$ & $-0.001^{* *}(-2.51)$ & $0.002(0.80)$ & $0.005^{* * *}(3.11)$ \\
\hline PayCboth $_{t-1}$ & $-0.003(-1.56)$ & $0.012^{* * *}(4.49)$ & $-0.001(-0.10)$ & $0.011^{* * *}(4.28)$ & $-0.001(-0.65)$ \\
\hline NumPayrise $_{t-1}$ & $0.004^{* * *}(7.31)$ & $-0.002(-1.61)$ & $-0.002^{* * *}(-8.36)$ & $0.007(0.73)$ & $0.003(0.36)$ \\
\hline NumPaycut $_{t-1}$ & $-0.003^{* * *}(-4.67)$ & $-0.002^{*}(-1.72)$ & $0.001(0.68)$ & $-0.002^{* *}(-2.13)$ & $-0.002^{* * *}(-3.70)$ \\
\hline \multicolumn{6}{|c|}{ Panel B Allocation of CF, importance and frequency of compensation and governance } \\
\hline$C F_{t}$ & $0.081^{* * *}(9.18)$ & $0.615^{* * *}(40.64)$ & $0.125^{* * *}(34.57)$ & $-0.010(-0.73)$ & $-0.168^{* * *}(-16.68)$ \\
\hline$E C d i f_{t-1}$ & $-0.003(-0.82)$ & $0.004(0.63)$ & $-0.003^{* * *}(-21.32)$ & $-0.001^{* *}(-2.37)$ & $-0.002^{* * *}(-3.83)$ \\
\hline$L P G_{t-1}$ & $-0.004(-0.18)$ & $0.007^{*}(1.89)$ & $-0.003^{* * *}(-3.00)$ & $-0.001(-0.38)$ & $0.004^{*}(1.74)$ \\
\hline$S P G_{t-1}$ & $0.008(0.61)$ & $-0.005^{* *}(-2.02)$ & $-0.002^{* * *}(-3.93)$ & $-0.004^{* *}(-2.02)$ & $-0.002(-1.01)$ \\
\hline Payrise $_{t-1}$ & $0.007^{* * *}(4.17)$ & $-0.009^{* * *}(-3.17)$ & $-0.008(-1.20)$ & $-0.010^{* * *}(-4.16)$ & $0.007^{* * *}(4.17)$ \\
\hline Paycut $_{t-1}$ & $0.001(1.05)$ & $0.007^{* * *}(3.10)$ & $-0.002^{* * *}(-2.62)$ & $0.002(1.08)$ & $0.005^{* * *}(3.08)$ \\
\hline
\end{tabular}




\begin{tabular}{|c|c|c|c|c|c|}
\hline & (1) $\Delta C a s h_{t}$ & (2) $I n v_{t}$ & (3) $\mathrm{Div}_{t}$ & (4) $\Delta D_{t}$ & (5) $\Delta E_{t}$ \\
\hline PayCboth $_{t-1}$ & $-0.002(-1.52)$ & $0.013^{* * *}(4.73)$ & $0.002(0.25)$ & $0.012^{* * *}(4.63)$ & $-0.001(-0.62)$ \\
\hline NumPayrise $_{t-1}$ & $0.004^{* * *}(6.88)$ & $-0.002^{*}(-1.72)$ & $-0.002^{* * *}(-8.14)$ & $0.008(0.88)$ & $-0.002(-0.26)$ \\
\hline NumPaycut $_{t-1}$ & $-0.003^{* * *}(-4.55)$ & $-0.002^{*}(-1.86)$ & $-0.001(-0.11)$ & $-0.002^{* * *}(-2.63)$ & $-0.002^{* * *}(-3.49)$ \\
\hline$C E O^{\text {Gender }}$ & $0.02^{* * *}(4.41)$ & $0.031^{* * *}(4.03)$ & $0.09^{* * * *}(4.81)$ & $0.028^{* * *}(3.96)$ & $0.031^{* * *}(6.09)$ \\
\hline$C E O^{\text {Tenure }}$ & $-0.001^{* *}(-1.98)$ & $0.004^{* * *}(4.07)$ & $-0.001(-0.42)$ & $0.005^{* * *}(4.80)$ & $-0.002^{* *}(-2.31)$ \\
\hline Dirs $^{\text {Non }}$ & $0.013^{* *}(1.99)$ & $0.009(0.81)$ & $-0.012^{* * *}(-4.50)$ & $-0.018^{*}(-1.71)$ & $0.028^{* * *}(3.67)$ \\
\hline$C E O^{O_{\text {wner }}}$ & $0.006^{* * *}(3.03)$ & $-0.008^{* *}(-2.39)$ & $0.001(1.16)$ & $-0.009^{* * *}(-2.93)$ & $0.009^{* * *}(3.99)$ \\
\hline Industry FE/year FE & Yes & Yes & Yes & Yes & Yes \\
\hline No. of firms & 711 & 711 & 711 & 711 & 711 \\
\hline
\end{tabular}

Notes: This table presents the results of cash-flow sensitivity on various uses to the distinct type of executive compensation. For each top manager, the independent variable $L P G_{t-1}$ is dummy and equal to one if pay is more than the largest 10 percentages of executive compensation (TDC2) growth. $S P G_{t-1}$ is dummy and equal to one if pay is less than the smallest 10 percentages of TDC2 growth. Payrise $t_{t-1}$ is dummy and equal to one if pay is more than the seventh decile of TDC2 growth, Paycut $t_{t-1}$ is dummy and equal to one if pay is less than the third decile of TDC2 growth. The indictor PayCboth $h_{t-1}$ equal to one if Payrise $_{t-1}=1$ and Paycut $_{t-1}=1$. NumPayrise $t_{t-1}$ is the number of pay rise if pay growth is larger than seventh decile of TDC2. NumPaycut $t_{t-1}$ is the number of pay cut if pay growth is smaller than third decile of TDC2 during CEO's tenure. Coefficients significant at the $10 \%, 5 \%$, and $1 \%$ levels are indicated by *, **, and ${ }^{* * *}$, respectively. The t-statistics are presented in parentheses.

The aim of Table 5 is to investigate the distinct type of CEO compensation packages in determining the cash flow sensitivity for various uses in firms. Previous studies report that variation in CEO compensation can play an important role in improving the managerial performance. However, there has been no evidence on how the change in CEO compensation influence allocation of internal cash flow in firms with controlling relating variables. Recent literature has stressed the incentive pay to CEO may lose their power over time: if firm value declines, options may fall out of the money and bear little sensitivity to the stock price [23]. Thus, the CEO may be able to engage in private saving to achieve a higher future income than intended by the contract, in turn reducing his effort incentives. Moreover, Malmendier, Tate and Yan [27] provide evidence that overconfident CEOs with optimistic beliefs display higher investment-cash flows sensitivities, are more acquisitive, and are less likely to rely on equity financing than their peers. On the contrary, Otto [30] find that CEOs with optimistic beliefs receive smaller stock option grants, fewer bonus payments, and less total compensation than their peers. These findings add to our understanding of the interplay between managerial biases and remuneration and show possibility that sophisticated adjustment of compensation can play an active role in corporate making decision.

In Table 5, we examine whether the variation in executive compensation matters in setting allocation of internal cash flow relative to peers. Our results show that the impact of CEO compensation on uses of cash flow varies, depending on whether CEO pay increases and declines. We observe that rise in compensation has a positive and significant impact on the cash holding sensitivity, while negative and significant impact on the investment-cash flows sensitivity. This finding suggests that, contrary to some anecdotal evidence, rise in CEO compensation seems to increase allocation of internal cash flow to cash holding and decline allocation of internal cash flow to investment. However, fall in CEO compensation creates positive and significant impact on investment-cash flows sensitivity. In light of the proposal of Goergen and Renneboog [25], these results can be interpreted as an attempt by self-serving executives skim corporate profits and expropriate shareholders, to link managerial compensation to firm's allocation of cash flow. This finding is consistent with most of the existing literature supports the view that executives tend to benefit from windfall earnings and are able to extract rents in the presence of weak corporate governance. We also find that the number of pay rises and falls affect the fraction of cash flow sensitivity, which might reflect CEOs' attempt to link pay with allocation of cash flow. The results for rises and falls in CEO compensation control dummies and other control variables in Panel B are similar to those presented in Panel A.

Table 6. Allocation of internal cash flow and incentive compensation by using industry-based peer group.

\begin{tabular}{|c|c|c|c|c|c|}
\hline & (1) $\Delta$ Cash $_{t}$ & (2) $I n v_{t}$ & (3) Div & (4) $\Delta D_{t}$ & (5) $\Delta E_{t}$ \\
\hline \multicolumn{6}{|c|}{ Panel A Allocation of CF and incentive compensation } \\
\hline$C F_{t}$ & $0.101^{* * *}(6.55)$ & $0.566^{* * *}(22.31)$ & $0.159^{* * *}(21.87)$ & $-0.020(-0.98)$ & $-0.153^{* * *}(-8.99)$ \\
\hline$C / O_{t-1}$ & $0.002^{* * *}(3.58)$ & $-0.002^{* * *}(-2.81)$ & $-0.001(-0.53)$ & $-0.001(-1.19)$ & $0.001(0.23)$ \\
\hline$R I M E 2 T_{t-1}$ & $0.002(0.68)$ & $0.035^{* * *}(6.63)$ & $-0.007(-0.43)$ & $0.027^{* * *}(6.30)$ & $0.009^{* * *}(2.79)$ \\
\hline$R I M E 2 U_{t-1}$ & $-0.001^{*}(-1.65)$ & $-0.002^{* * *}(-2.96)$ & $-0.001(-0.06)$ & $-0.001(-1.56)$ & $-0.002^{* * *}(-4.51)$ \\
\hline$E_{X E C R A N K_{t-1}}$ & $0.002^{* * *}(3.61)$ & $0.003^{* * *}(3.09)$ & $-0.002^{* * *}(-6.09)$ & $0.002^{* * *}(2.61)$ & $0.001(1.55)$ \\
\hline \multicolumn{6}{|c|}{ Panel B Allocation of CF, incentive compensation and governance } \\
\hline$C F_{t}$ & $0.099^{* * *}(6.44)$ & $0.573^{* * *}(22.62)$ & $0.157^{* * *}(21.77)$ & $-0.017(-0.84)$ & $-0.153^{* * *}(-9.08)$ \\
\hline$C / O_{t-1}$ & $0.002^{* * *}(3.69)$ & $-0.002^{* * *}(-3.22)$ & $-0.001(-0.19)$ & $-0.001(-1.08)$ & $-0.001(-0.26)$ \\
\hline$R I M E 2 T_{t-1}$ & $0.002(0.51)$ & $0.033^{* * *}(6.23)$ & $-0.001(-0.55)$ & $0.027^{* * *}(6.28)$ & $0.007^{* *}(1.74)$ \\
\hline RIME $2 U_{t-1}$ & $-0.001(-1.41)$ & $-0.002^{* *}(-3.06)$ & $0.001(0.32)$ & $-0.001^{*}(-1.68)$ & $-0.002^{* * *}(-4.17)$ \\
\hline
\end{tabular}




\begin{tabular}{|c|c|c|c|c|c|}
\hline & (1) $\Delta$ Cash $_{t}$ & (2) $I n v_{t}$ & (3) $\mathrm{Div} \mathrm{t}_{t}$ & (4) $\Delta D_{t}$ & (5) $\Delta E_{t}$ \\
\hline EXECRANK $_{t-1}$ & $0.002^{* * *}(2.32)$ & $0.001(0.92)$ & $-0.001^{* * *}(-3.86)$ & $0.003^{* * *}(3.31)$ & $-0.002^{* * *}(-2.61)$ \\
\hline$C E O^{\text {Gender }}$ & $0.002(0.20)$ & $0.041^{* *}(2.46)$ & $0.015^{* * *}(3.18)$ & $0.025^{*}(1.86)$ & $0.032^{* * *}(2.94)$ \\
\hline$C E O^{\text {Tenure }}$ & $-0.005^{* *}(-5.05)$ & $0.001(0.73)$ & $-0.001^{* *}(-2.41)$ & $0.002(1.50)$ & $-0.008^{* * *}(-6.36)$ \\
\hline $\operatorname{Dirs}^{\text {Non }}$ & $-0.015(-1.11)$ & $0.111^{* * *}(4.93)$ & $-0.041^{* * *}(-6.33)$ & $-0.025(-1.36)$ & $0.081^{* * *}(5.39)$ \\
\hline$C E O^{\text {Owner }}$ & $-0.002(-0.49)$ & $0.021^{* * *}(3.23)$ & $-0.011^{* * *}(-5.76)$ & $0.001(0.20)$ & $0.008^{*}(1.85)$ \\
\hline Industry FE/year FE & Yes & Yes & Yes & Yes & Yes \\
\hline No. of firms & 711 & 711 & 711 & 711 & 711 \\
\hline
\end{tabular}

Notes: This table presents the results of the panel regression analysis of the subsequent cash-flow sensitivity on various uses to the changes in incentive-pay of CEO compensation. For each top manager during his/her tenure, the independent variable Cash/Options $_{t-1} \quad\left(C / O_{t-1}\right)$ is defined by the ratio of cash-based salary and bonus to Compustat Black-Scholes options granted. RIME2T $T_{t-1}$ is the ratio of the estimated value of in-the-money exercisable options to the TDC2. $R I M E 2 U_{t-1}$ is ratio of the estimated value of in-the-money exercisable options to the value of un-exercisable options. EXECRANK ${ }_{t-1}$ is executive rank by salary and bonus. Coefficients significant at the $10 \%, 5 \%$, and $1 \%$ levels are indicated by $*, * *$, and $* * *$, respectively. The t-statistics are presented in parentheses.

In Table 6 , we take a closer look at the role of incentive compensation in determining the allocation of cash flow in firms compared to their peers and other governance control variables. Consistent with the results of Table 5, where we use the ratio of cash-based salary and bonus to Black-Scholes options granted as an independent variable ( $\mathrm{Cash} /$ Options $_{t-1}$, $C / O_{t-1}$ ) for incentive-pay, we report in second row that higher incentive-pay is associated with higher sensitivity on cash holding but lower sensitivity on investment in firms. We observe that equity-based compensation is in favor of increasing the fraction of allocation of cash flow for self-serving. However, as indicated by the significant coefficient of the investment, the impact of equity-based compensation on the fraction of cash flow allocation is less in firms than in the industry-based peers. In equity-ratio panel regressions, the coefficient estimate is positive on cash holding, while it is negative for investment. Thus, firms with more equity compensation tend to increase the sensitivity on cash holding and reduce the sensitivity on investment when CEOs can have an opportunity to offer a possibly allocation of various uses of cash flow.

In addition, we split equity-ratio into two groups: the ratio of the estimated value of in-the-money exercisable options to the TDC2 and ratio of the estimated value of in-the-money exercisable options to the value of un-exercisable options. While we find that equity-based compensation does not have a significant impact on the cash holding sensitivity, it does have a significant impact on the fraction of cash flow sensitivity on investment and external financing in firms. Finally, CEOs having a high ranking of salary and bonus relative to their colleague seems to have a positive impact on the fraction of cash holding sensitivity and investment-cash sensitivity, while it has a negative impact on sensitivity on dividend payout in firms.

\section{Conclusion}

The allocation of internal cash flow is most important decision in business operation. An applicable management of cash flow allocation creates either the incremental value to its shareholders or the excellent performances of top managers such that shareholders are willing to pay high compensation to top managers. However, the cash flow allocation would not have alignment with benefits of shareholders because of a divergence between control rights and cash flow rights has a significantly negative effect on the pay-performance relationship.

A fair number of firms have opted to provide the distinct incentive-pay structure to top managers to link the performance and compensation. Critics of performance-based compensation structure are concerned that firms with the choice of highly paid peers as benchmark of compensation may reduce managing effectiveness by executives and create a setting that provides the CEOs with more opportunities to make self-serving decisions. These views seem quite predominant in spite of the lack of definite conclusions in the literature regarding the implications of performance-based compensation structure. Our analysis suggests that firms choose their allocation of cash flow by an assessment of the alternative compensation structures based on their business and governance environments. We document negative effect on the investment-cash sensitivity implications, on average, for the firms with the high compensation differential that have low investment-cash sensitivity after controlling the choice of highly paid peers.

In sum, our paper provides evidence on the implications of cash flow allocation in the choice of compensation structure and governance environment. More importantly, we are the first to document a link between economic determinants of compensation structures and the corresponding cash-flow sensitivity consequences. Our evidence is consistent with the notion that, on average, firms allocate their internal cash flow based on their business environments, and proponents calling for firms to maintain the compensation structure with the choice of highly paid peers should carefully consider the incentive-pay and performance-linkage reasons underlying firms' compensation decisions.

\section{Acknowledgements}

The authors are grateful for the financial support provided by the Ministry of Science \& Technology, Taiwan MOST 105-2410-H-002-047-). 


\section{References}

[1] Abel, A. B., 1990, Asset prices under habit formation and catching up with the joneses, American Economic Review 80, $38-42$.

[2] Abowd, J. M., F. Kramarz, and D. N. Margolis, 1999, High wage workers and high wage firms, Econometrica 67, 251-333.

[3] Albuquerque, A. M., G. De Franco, and R. S. Verdi, 2013, Peer choice in ceo compensation, Journal of Financial Economics $108,160-181$

[4] Almeida, H., M. Campello, and M. S. Weisbach, 2004, The cash flow sensitivity of cash, Journal of Finance 59, 1777-1804.

[5] Almeida, Heitor, and Murillo Campello, 2007, Financial constraints, asset tangibility, and corporate investment, Review of Financial Studies 20, 1429-1460.

[6] Almeida, Heitor, and Murillo Campello, 2010, Financing frictions and the substitution between internal and external funds, Journal of Financial and Quantitative Analysis 45, 589-622.

[7] Amoako-Adu, B., V. Baulkaran, and B. F. Smith, 2011, Executive compensation in firms with concentrated control: The impact of dual class structure and family management, Journal of Corporate Finance 17, 1580-1594.

[8] Balafas, N., and C. Florackis, 2014, Ceo compensation and future shareholder returns: Evidence from the london stock exchange, Journal of Empirical Finance 27, 97-115.

[9] Bebchuk, L. A., and J. A. Fried, 2003, Executive compensation as an agency problem, Journal of Economic Perspectives 17, 71-92.

[10] Benmelech, Efraim, Eugene Kandel, and Pietro Veronesi, 2010, Stock-based compensation and ceo (dis)incentives, Quarterly Journal of Economics 125, 1769-1820.

[11] Bizjak, John, Michael Lemmon, and Nguyen Thanh, 2011, Are all ceos above average? An empirical analysis of compensation peer groups and pay design, Journal of Financial Economics $100,538-555$.

[12] Bizjak, John M., Michael L. Lemmon, and Lalitha Naveen, 2008 , Does the use of peer groups contribute to higher pay and less efficient compensation? Journal of Financial Economics 90, 152-168.

[13] Brick, I. E., O. Palmon, and J. K. Wald, 2006, Ceo compensation, director compensation, and firm performance: Evidence of cronyism, Journal of Corporate Finance 12, 403-423.

[14] Cai, J., and R. A. Walkling, 2011, Shareholders' say on pay: Does it create value? Journal of Financial and Quantitative Analysis 46, 299-339.

[15] Campbell, J. Y., and J. H. Cochrane, 1999, By force of habit:
A consumption-based explanation of aggregate stock market behavior, Journal of Political Economy 107, 205-251.

[16] Cao, J., X. F. Pan, and G. Tian, 2011, Disproportional ownership structure and pay-performance relationship: Evidence from china's listed firms, Journal of Corporate Finance 17, 541-554.

[17] Capezio, A., J. Shields, and M. O'Donnell, 2011, Too good to be true: Board structural independence as a moderator of ceo pay-for-firm-performance, Journal of Management Studies 48, 487-513.

[18] Cebon, P., and B. E. Hermalin, 2015, When less is more: The benefits of limits on executive pay, Review of Financial Studies $28,1667-1700$.

[19] Chang, X., S. Dasgupta, G. Wong, and J. Q. Yao, 2014, Cash-flow sensitivities and the allocation of internal cash flow, Review of Financial Studies 27, 3628-3657.

[20] Chang, Yuk Ying, Sudipto Dasgupta, and Gilles Hilary, 2010, Ceo ability, pay, and firm performance, Management Science $56,1633-1652$.

[21] Core, J. E., R. W. Holthausen, and D. F. Larcker, 1999, Corporate governance, chief executive officer compensation, and firm performance, Journal of Financial Economics 51, 371-406.

[22] Dey, A., E. Engel, and X. H. Liu, 2011, Ceo and board chair roles: To split or not to split? Journal of Corporate Finance 17, 1595-1618.

[23] Edmans, Alex, Xavier Gabaix, Tomasz Sadzik, and Yuliy Sannikov, 2012, Dynamic ceo compensation, Journal of Finance 67, 1603-1647.

[24] Gao, H. S., J. Harford, and K. Li, 2012, Ceo pay cuts and forced turnover: Their causes and consequences, Journal of Corporate Finance 18, 291-310.

[25] Goergen, Marc, and Luc Renneboog, 2011, Managerial compensation, Journal of Corporate Finance 17, 1068-1077.

[26] Kaustia, M., and V. Rantala, 2015, Social learning and corporate peer effects, Journal of Financial Economics 117, 653-669.

[27] Malmendier, Ulrike, Geoffrey Tate, and Jon Yan, 2011, Overconfidence and early-life experiences: The effect of managerial traits on corporate financial policies, Journal of Finance 66, 1687-1733.

[28] Milbourn, T. T., 2003, Ceo reputation and stock-based compensation, Journal of Financial Economics 68, 233-262.

[29] Minnick, K., and L. Rosenthal, 2014, Stealth compensation: Do ceos increase their pay by influencing dividend policy? Journal of Corporate Finance 25, 435-454.

[30] Otto, Clemens A., 2014, Ceo optimism and incentive compensation, Journal of Financial Economics 114, 366-404. 